\title{
Continuity and change in social policy approaches toward women
}

\author{
Azer Kılıç
}

\begin{abstract}
This article discusses the development of social policy in Turkey from a gender perspective. Focusing on continuities and changes in the formal social security system and the labor market regulation, it aims to describe the place of women in social policy until today. I argue that social policy measures from the late Ottoman era to the single-party period laid the foundation for later gendered policy approaches through specific assumptions on women's roles and position. With the introduction of a modern social security system in the post-World War II period women have increasingly become integrated into the system, either as workers or as dependents of workers; however, assumptions about women's place in the family and the labor market did not change much. Familial dependency and traditional gender norms were assumed and reinforced through certain gender-differentiated policies, and women workers have been encouraged to go back home. Over the last two decades, however, the conceptualization of women in social policy formulations has shifted towards a policy that encourages female labor and equal treatment of genders.
\end{abstract}

Keywords: social policy, protective legislation, gender, equality/difference, Turkey

Azer Kılıç, Boğaziçi Üniversitesi Sosyal Politika Forumu, 34342, İstanbul, Turkey, azerkilic@gmail.com. Author's note: This article relies on the research I conducted for my MA thesis, Gender and Social Policy in Turkey: Positive Discrimination or a Second-Class Female Citizenship? (Boğaziçi University, 2006). I would like to thank Ayşe Buğra for her helpful suggestions and the Boğaziçi University Social Policy Forum for its financial support. 


\section{Introduction}

Recent debates on the demands for incorporating a women-quota in the parliament into the new constitution highlight the role of law in constituting gendered identities, along with showing various actors' diverse positions concerning the relationship between gender equality and representative politics. Clearly, law does not merely reflect gender relations in society, but also plays an active role in shaping gendered subjects, and legal discourses, rules, and institutional arrangements suggest a particular subjectification of persons in relation to others. ${ }^{1}$ Here, social policy is another legal site for the constitution and enactment of gendered identities and capabilities.

Over the last two decades, feminist scholarship has paid great attention to the labor market structure. Scholars have engaged in field research and gender analysis, ranging in focus from formal to informal economy; from sectoral and occupational distribution of labor to income disparities; from unionism to sexual harassment in the workplace; from globalization and macro-economic policies to immigration. ${ }^{2}$ Yet, the place of women in social policy, and especially the gender dimension of the social security system, have been somewhat neglected within this rich literature, both in historical and contemporary terms. ${ }^{3}$ However, one may observe a recent increase in interest in the topic, parallel to the ongoing social security reform as well as gender policies of the European Union (EU). ${ }^{4}$

This article aims to contribute to a historical analysis of social policy approaches toward women, focusing on the legal arrangements both for

1 Nicola Lacey, "The Constitution of Identity: Gender, Feminist Legal Theory, and the Law and Society Movement," in The Blackwell Companion to Law and Society, ed. Austin Sarat (Malden: Blackwell, 2004).

2 Examples include Belkıs Kümbetoğlu, "Women's Informal Sector Contribution to the Household Survival in Urban Turkey" (Ph.D. Diss., Istanbul, 1992), Aksu Bora, Kadınların Sınıfi: Ücretli Ev Emeği ve Kadın Öznelliğinin Inşası (İstanbul: İletişim, 2005), Gülay Toksöz and Seyhan Erdoğdu, Sendikacı Kadın Kimliği (Ankara: İmge, 1998), Ferhunde Özbay, ed., Küresel Pazar Açısından Kadın Emeği ve Istihdamındaki Değişmeler: Türkiye Örneği (İstanbul: Insan Kaynağını Geliştirme Vakfi, 1998), Aygül Oktay, "iş Yerinde Cinsel Taciz ve Istismar," Kadın Araştırmaları Dergisi, 7 (2001), İpek Ilkkaracan "Göç, Kadının Ekonomik Konumu, Hareket Ozgürlüğü ve Aile İçi Güç Dinamikleri," iktisat Dergisi, 67 (March 1998).

3 Studies include Tülay Arın and Berin Ergin, "Türkiye'de Sosyal Güvence ve Kadınlar: Yasal Çerçeve ve Uygulama," in Aydinlanmanin Kadınlan, ed. Necla Arat (Istanbul: Cumhuriyet Kitapları, 1998), Fatma Senden Zırhlı, Sosyal Güvenlik ve Kadın (Istanbul: Minerva, 2000), Meryem Koray, Sosyal Politika (Ankara: İmge, 2005), Yıldız Ecevit, "Women's Labour and Social Security," in Bridging the Gender Gap in Turkey: A Milestone Towards Faster Socio-economic Development and Poverty Reduction, ed. Feride Acar (Poverty Reduction and Economic Management Unit: World Bank, 2003).

4 Gülnur Acar-Savran, "AB'nin Toplumsal Cinsiyet Politikaları," Birikim, 204 (April 2006), Selma Acuner, "Avrupa Birliği ve Eşitlik Politikaları: Çetrefil Bir Yol!" Amargi, 2 (Fall 2006). This article was written before the amendment proposal for the reform bill on social security and healthcare; feminist reactions took place mostly after this date. See, for instance, Gülnur Acar-Savran, "Sosyal Güvenlik 
social security and the labor market. Gender differentiation and neutralization in these policies throughout the modern history of Turkey will provide the trajectory to trace the place of women in social policy. This trajectory relates to the so-called "equality-versus-difference" debate on feminist principles and political strategies. While those on the equality axis support equal treatment of women and men with regard to rights and obligations, those on the difference axis claim women's special needs and support a different treatment of genders. Here, the former approach is mostly criticized for the risks of universalism of male terms and assimilation of women to the male ideal, while the latter approach is criticized for the risks of essentializing gender stereotypes, stigmatizing women as inferior, and justifying gender inequalities with its appeals to female difference. Concrete examples, however, show that the terms have different meanings in different situations and that we need to move beyond this dichotomy. ${ }^{5}$

Feminist scholars and activists in post-1980 Turkey have generally leaned towards the difference axis and supported positive discrimination policies to achieve an equal status. ${ }^{6}$ In the realm of social policy, positive discrimination policies have been supported in the form of quotas in the decision-making bodies of labor unions and in male-dominated occupations. ${ }^{7}$ As I will show below, social security policies present further examples of a different treatment of genders, examples which seem quite complicated and need to be problematized in their specific context. Benefiting from the equality-or-difference debate as an analytical framework, rather than as a normative dichotomy, this article explores the mentality behind these gender-specific policies.

Family and kinship solidarity have played a significant role in welfare provision in Turkey, because the formal social security system has been insufficient to provide social protection to large segments of the population

Reformu Karşısında Feminist Politika," Bianet (4 January 2008), Bianet, "Kadınlar Sosyal Güvenlik Reformuna Karşı Eylem Hazırlığında" (31 December 2007).

5 Joan W. Scott, "Deconstructing Equality-versus-Difference: Or, the Uses of Post-structuralist Theory for Feminism," Feminist Studies, 14, 1 (Spring 1988), Gisela Bock and Susan James, "Introduction: Contextualizing equality and difference," in Beyond Equality and Difference: Citizenship, Feminist Politics, and Female Subjectivity, ed. Gisela Bock and Susan James (London, NY: Routledge, 1992).

6 Yeşim Arat, "Türkiye'de Toplumsal Cinsiyet ve Vatandaşlık," in 75 Yılda Tebaa'dan Yurttaş'a Doğru, ed. Artun Ünsal (İstanbul: Tarih Vakfi, 1998). For those who stress the need to reach beyond such a dichotomous line of reasoning, see, for instance, Cülnur Acar-Savran, Beden, Emek, Tarih: Diyalektik Bir Feminizm için (İstanbul: Kanat, 2004).

7 For recent examples, see Toksöz and Erdoğdu, Sendikacı Kadın Kimlï̈i, Cülnur Acar Savran, interview, "Ev İşleri Bütün Bir Hayata Yayllı,," Pazartesi, 112 (February-March 2007), Anon. "Pozitif Ayrımcılık Bize Fena Halde Gereklidir..." Petrol-is Kadın, 9 (June 2004), and KESK, "Olumlu Eylem ve Cüçlendirme Raporu," 2004, Bianet, "Kadın Istihdamı için Talepler: Pozitif Ayrımcllık" (11 December 2007). 
since self-employment, unpaid family labor, and informal employment practices take an important place in the labor market structure. ${ }^{8}$ In parallel to such a policy environment, this article argues that most of the longlasting gender-differentiated policies for the "protection of destitute women" indeed reinforce women's dependence on the male-headed family unit and the gender division of labor in the domestic sphere, in addition to stigmatizing them. Accordingly, social policy approaches generally have not perceived women as an important component of the labor force and, consequently, not supported them; even working women have been encouraged to go back home through several incentives.

The welfare system, however, has been undergoing a significant transformation in the last decade, a transformation which has now reached its most controversial phase with the recent reform initiatives regarding the social security and healthcare system. ${ }^{9}$ Various factors have been influential in this process, such as concerns about fiscal crises; pressures by the International Monetary Fund (IMF), the World Bank, and national business circles for budgetary discipline; societal and labor-union demands for the protection of social rights; the conservative liberalism of the current Justice and Development Party (Adalet ve Kalknma Partisi-AKP) government; and the changing socio-economic structure of the country, which negatively affected old informal mechanisms of solidarity. ${ }^{10}$ The gender dimension of social policy has also been altered during this process, especially triggered by the EU directives on gender equality included in Turkey's National Program for the adoption of the Acquis Communautaire. ${ }^{11}$ Considering these recent changes, this article shows that new social policies tend towards the equal treatment approach, but mostly in the form of a decrease of entitlements formerly enjoyed by women rather than an extension of these entitlements to men as well; this is likely to put women in a vulnerable position, considering the traditional gender division of labor at home and the gendered structure of the labor market. Nevertheless, the changes also signal a shift toward a policy of encouraging female employment.

8 Ayşe Buğra and Çağlar Keyder, "Turkish Welfare Regime in Transformation," Journal of European Social Policy, 16, 3 (2006).

9 Sosyal Sigortalar ve Genel Sağlik Sigortası Kanunu, Law No. 5489, adopted on April 19, 2006. As we know, some of the provisions of the law were annulled by the Constitutional Court in December 2006, and the AKP government has prepared an amendment draft in November of 2007, which is now on the parliament's agenda. Below I will examine the law of 2006, but not elaborate on the amendment draft which proposes changes in gender terms as well and again faces opposition from various segments of society, including feminists, labor unions, and the chamber of doctors.

10 Buğra and Keyder, "Turkish Welfare Regime in Transformation."

11 "Avrupa Birliği Müktesebatının Üstlenilmesine ilişkin Türkiye Ulusal Programı," Resmi Gazete, no: 25178, July 24, 2003. 
I will first give a survey of the Late Ottoman and Early Republican policies. Since the development of the formal social security system mainly took place after World War II, this period will be the main focus of the study, as it will explore the development of each insurance branch from a gender perspective. Due to the long time span and diversity of policy issues, this evaluation limits itself to major legislative arrangements and accompanying discourses by policy-making elites, even though there were different factors and several problems involved in the process of implementation.

\section{From the late Ottoman to the early republican era}

The development of social security mechanisms can be traced back to the late Ottoman era. ${ }^{12}$ Because of the wars in the second half of the nineteenth and early twentieth century, this was an era when social problems needed to be addressed and controlled, and when the state and its policies needed to maintain legitimacy. Hence, initial schemes provided benefits to the survivors of military and civil officials of the state through retirement and solidarity funds (tekaüd ve teavün sandikları), in addition to other mechanisms such as the Wage for Families without Breadwinner (muinsiz aile maaşı) to help the families of mobilized soldiers; ${ }^{13}$ orphan funds (eytam sandiklari), which were not only for orphans, but also for widows; and orphanages (darüleytam, 1914).

The gendered policy in some of these practices exhibits a relative continuity with the survivor policies of the Republican period. In many cases, different benefits were provided for orphans based to their sex. From the orphan funds, male orphans were paid pensions until 20 years of age, while female orphans were entitled to pensions as long as they were single; on the other hand, the amount of pensions for males was more than that for females. The condition about marital status was also binding for widows entitled to pensions. Widows were obliged to regularly prove their marital status to be able to receive their payments. ${ }^{14}$ The same policy also applied

12 For the development of social security measures in Ottoman society, see Eyüp Sabri Kala, "Osmanlılarda Sosyal Güvenlik-Sosyal Sigortalar: (1865-1923)" (MA Thesis, İstanbul Üniversitesi, 1994), Tahsin Ozcan, "Osmanlı Toplumunda Sosyal Güvenlik Üzerine Bazı Gözlemler," in Osmanlı (Ankara: Yeni Türkiye Yayınları, 1999), Nadir Ozbek, Osmanlı Imparatorluğu'nda Sosyal Devlet: Siyaset, iktidar ve Meşruiyet, 1876-1914 (İstanbul: Iletişim, 2004).

13 Nicole A. N. M. Van Os, "Asker Ailelerine Yardım: Osmanlı Devleti ve Muinsiz Aile Maaşı," in Devletin Silahlanmasi: Ortadoğu ve Orta Asya'da Zorunlu Askerlik, 1775.1925, ed. Erik ). Zürcher (Istanbul: İstanbul Bilgi Üniversitesi Yayınları, 2003).

14 Mehmet Çanlı, "Eytam Idaresi-Sandıkları ve Osmanlı Devletinde Yetimlerin Ekonomik Haklarının Korunması," in Savaş Çocukları: Öksüzler ve Yetimler, ed. Emine Gürsoy-Naskali and Aylin Koç (istanbul: [s.n.], 2003), Mehmet Çanlı, “Eytam Idaresi ve Sandıkları (1851-1926)," in Türkler (Ankara: Yeni Türkiye Yayınları, 2002). 
to some of the regulations concerning the retirement funds, which meant that pensions for female survivors could be for lifetime in case of severe invalidity and insanity and were re-payable in case of divorce or becoming a widow for a second time. ${ }^{15}$

The early Republican state did not initiate any centralized mechanism for social security while various separate funds were established for civil servants, workers in the public sector, and several other occupational groups. ${ }^{16}$ Of these funds, the Military and Civil Retirement Fund of 1930 brought together the earlier funds established during the late Ottoman era under a single scheme and with a similar gender policy. The fund gave survivor benefits primarily to wife and children, and if they did not exist, then to the widowed mother and the destitute or invalid husband and father. Widows were entitled to the pension until they remarried, while the invalid who could not work was entitled to a lifelong pension regardless of sex. As for orphans, they were subject to age-limits and, in case of daughters, marital status to be eligible for benefits. ${ }^{17}$

As for the labor market, while there had been failed initiatives to regulate the working conditions of women and children with regard to night-work and hard and dangerous working conditions during the Young Turk era, ${ }^{18}$ the Law on Public Hygiene of 1930 arranged protective measures for women and children for the first time, bringing some prohibitions and restrictions on working conditions as well as providing maternity benefits; however, the provisions were not necessarily put into practice due to the absence of supervision in the workplace. ${ }^{19}$ The law

15 See the regulation dated to September 27, 1874 and entitled "Infak-ı Muhtacin-i Eytam ve Eramil-i ilmiyye Nizamnamesi," the regulation dated to 26 September 1880 and entitled "Memurin-i Mülkiye Terakki ve Tekaüd Kararnamesi;" the amendment regulation dated to April 13, 1889 and entitled "No: 77-2 zilkade 1305 tarihli devairi askeriyede müstahdem memurin ve ketebei tekaüd nizamnamesinin 19 ve 21 inci maddesi musahhasi;" and the amendment regulation dated to October 10,1889 and entitled "No: 119-Erkan, ümera ve zabitanı askeriyeden vefat edenlerin eytam ve eramiline tahsis olunacak maaşlara mütedair 12 şaban 1306 tarihli 5 inci maddei musahhasına müzeyyel fikrai nizamiye" in Kamu Personeli Emeklilik Mevzuatı 1 (1876-1930) (Ankara, Maliye Bakanlığı Bütçe ve Mali Kontrol Genel Müdürlügü, 1994). For similar requirements on marital status, see the regulation dated to June 27, 1910 and entitled "Muhtacın Maaşatı Hakkında Nizamname," in Republic of Turkey, Düstur, 2nd Tertib, vol. 2, 400-03.

16 For a collection of these legal arrangements, see Kamu Personeli Emeklilik Mevzuatı II (1930-1950) (Ankara, Maliye Bakanlığı Bütçe ve Mali Kontrol Genel Müdürlügü, 1995). For the development of the welfare system throughout the Republican period, see, Nadir Özbek, Cumhuriyet Türkiyesi'nde Sosyal Güvenlik ve Sosyal Politikalar (İstanbul: Tarih Vakf, 2006), Ayşe Buğra, "Poverty and Citizenship: An Overview of the Social Policy Environment in Republican Turkey," International Journal of Middle East Studies, 36 (2007).

17 Askeri ve Mülki Tekaüd Kanunu, Law No. 1683, adopted on 3 June 1930.

18 Zafer Toprak, "Sosyal Politika Tarihimizin Ilk Önlemler Paketi: Müessesat-ı Sınaiyyede Çocukların ve Kadınların Çalıştırılması (1910)," Toplum ve Bilim 27 (Fall 1984).

19 Özbek, Cumhuriyet Türkiyesi'nde Sosyal Güvenlik ve Sosyal Politikalar, 130. 
banned pregnant women from working three weeks before and after delivery and barred them for a three-month period before the delivery from employment in hard work. Also, nursing breaks (up to half an hour twice a day) were provided for six months following the delivery. ${ }^{20}$ In parallel with the pro-natalist policies of the period, the law proposed measures to increase birth rates, to reduce infant mortality, and to improve health conditions. Accordingly, maternal hospitals and day nurseries were founded during this period. ${ }^{21}$

In 1936, the first Labor Law of the Republic was legislated, to remain in force until 1967. The law included provisions regarding the working conditions of women and children, as well as entitlements concerning maternity and healthcare in case of occupational diseases; however, workers rarely enjoyed these rights, since the necessary by-laws had not been arranged. ${ }^{22}$ Among these by-laws were the regulation of working conditions and prohibitions concerning pregnant and breast-feeding women; breast-feeding rooms and day nurseries; and the regulation of hard and dangerous work conditions for children and women. Nonetheless, the law prohibited the employment of men below the age of eighteen and women at any age underground or underwater, as well as their employment in night-work in industry, to be followed later by the ratification of "ILO Convention Concerning the Employment of Women on Underground Work in Mines of all Kinds" in 1937. Therefore, working conditions were regulated by these gender-specific provisions until the enactment of later labor laws which followed a similar direction.

Social protection policies during this period laid the basis for later different treatment policies according to a paternalist perspective and reinforced the male-breadwinner family model with a dependent role for women. Labor market regulations suited this portrait with gender-specific restrictions and "protection." The place of women in this approach was more or less in compliance with the existing socio-economic structure of the period; yet, the relevance of the model for the later period until today seems more problematic. The meanings of these gender-specific provisions can be understood better by looking at the later development of policies.

\section{Social security in the multi-party period}

In parallel to global post-World War II developments, welfare state policies gained more currency and application in Turkey as well, bringing about a

20 Umumi Hifzisihha Kanunu, Law No. 1593, adopted on 24 April 1930.

21 Özbek, Cumhuriyet Türkiyesi'nde Sosyal Cüvenlik ve Sosyal Politikalar, 92.

22 Ahmet Makal, Türkiye'de Tek Partili Dönemde Çalışma ilişkileri: 1920-1946 (Ankara: Imge, 1999), 425. 
gradual institutionalization and extension of social insurance, along with increasing labor market regulation. The result was a multi-fragmented corporatist social security system that provided health and pension benefits to persons on the basis of their labor market status. For civil servants, earlier arrangements were gathered under the single scheme of the Retirement Chest (Emekli Sandiğt-ES) in 1949. As for workers, schemes were established step by step starting in 1945 and culminating in the Social Insurance Institute (Sosyal Sigortalar Kurumu-SSK) under the 1964 Social Insurance Law. Finally, the Social Security Organization of Craftsmen, Tradesmen and Other Self-Employed Workers (Băg-Kur) was founded in 1971. Later, two less significant schemes were also integrated into the system in order to cover agricultural workers and self-employed farmers in the 1980s. During this entire process, there have been innumerable amendments to each of these regulations; either individual autonomous amendments or successive cross-amendments, culminating in the ongoing social security reform in the last decade. In the following section, I will examine the development of each insurance branch and protective labor legislation up to today, insofar as they introduce normative changes in terms of gender.

\section{Survivor insurance}

Gender differentiation in conditions and benefits for survivors has been one of the most enduring and distinctive characteristics of the social security system. To start with the policy regarding orphans, while initial arrangements for workers arranged the entitlement of orphans to survivor pensions regardless of sex ${ }^{23}$ the ES law of 1949 established the gendered norms later on adapted by other schemes for workers and the selfemployed as well. A daughter's entitlement to pension was legislated as lifelong and subject to suspension in case of marriage, formal employment, or receiving an income from social security institutions. ${ }^{24}$ Pensions were payable again if the reasons for suspension ended. In addition, girls were encouraged to marry via a lump-sum payment of pensions - that is, a "marriage bonus." On the other hand, sons were entitled only until a certain age, depending on educational and marital status. However, sons

23 is Kazaları, Meslek Hastalıkları ve Analik Sigortaları Hakkında Kanun, Law No. 4772, adopted on 27 June 1945, Ihtiyarlık Sigortası Kanunu, Law No. 5417, adopted on 02 June 1949, Maluliyet, ihtiyarlik ve Olüm Sigortaları Kanunu, Law No. 6900, adopted on 4 February 1957, and Sosyal Sigortalar Kanunu, Law No. 506, adopted on 17 |uly 1964.

24 Esnaf ve Sanatkarlar ve Diğer Bağımsız Çalışanlar Sosyal Sigortalar Kurumu Kanunu, Law No. 1479, adopted on 2 September 1971, 506 sayıl Sosyal sigortalar kanunun bazı maddelerinin değistirilmesi ve bu kanuna iki geçici madde eklenmesi hakkında kanun, Law No. 1753, adopted on 21 June 1973. 
were entitled to pensions for lifetime in case of severe invalidity, regardless of conditions, whereas the pensions of invalid daughters were terminated when they married. ${ }^{25}$ This policy was changed in 2003 to include invalid daughters for lifelong pensions, ${ }^{26}$ and the recent reform initiative introduced with the Law of Social Insurances and General Health Insurance in 2006 has furthered gender equalization through the extension of marriage allowances to sons who marry before their pensions formally end. ${ }^{27}$ Other than this, the reform preserves the gendered policy, including healthcare entitlements for the survivor pensioners, in contrast to the alteration in the entitlement of dependent children to healthcare as genderneutral, as I will show below.

As for survivor spouses, initial policies were similar to the differentiation in orphan benefits. As a lasting policy, widows have been entitled to pensions mainly under the condition of single marital status, and they have been encouraged to remarry via a marriage bonus under the ES scheme, whereas working status generally has not been a reason for the suspension of pensions, unlike with orphan pensions. On the other hand, widowers generally were tested for specific conditions like destitution, dependency on the wife, invalidity, and age limits. However, over time the policy on survivor spouses has moved towards equalization. The provisions of the three schemes concerning widow(er) pensions were amended in the mid$1980 \mathrm{~s}$ in order to equalize the rules for both sexes; hence, means-test and age-limit for men were removed, but marital status remained the main condition. ${ }^{28}$ The reform of 2006 completes the equal treatment of survivor spouses, extending marriage allowances to widowers as well.

In these arrangements one can observe that the texts about widows and orphans mostly embrace a paternalist and patriotic discourse of reciprocity, between the "dedication" of workers or the "sacrifice" of soldiers and the responsibility of the state to take care of their survivors in return. ${ }^{29}$ Here,

25 Emekli Sandiğı Kanunu, Law No. 5434, adopted on 8 June 1949. Lump-sum payments were equal to the total amount of pension paid in a year.

26 Amendments to exempt invalid daughters from other conditions similar to invalid sons have been legislated for Bag-Kur by Law No. 4956, adopted on 24 July 2003, and for the SSK by Law No. 4958, adopted on 29 July 2003.

27 Sosyal Sigortalar ve Genel Sağlik Sigortası Kanunu.

28 Bağkur was amended by Law No. 3165, adopted on 14 March 1985, SSK by Law No. 3168, adopted on 20 March 1985, and ES by Law No. 3284, adopted on 7 May 1986.

29 Parliamentary discussions include descriptions such as Kemal Zeytinoğlu's address to parliament: "After they dedicated the most efficient times of their life to the services of the state [...] to leave their widows and orphans to the chance of destiny in their death cannot be explained within an understanding of the modern state under the rule of law," in TBMM, Zabit Ceridesi, Term 8, Session 3, vol. 19, 18 May 1949, 500-01 [translation of this and the following passages mine]. General Eyüp Durukan remarked: "Retired persons withstood so many deprivations, took part in various wars, 
the state is mostly represented as the central actor, "the protector of the destitute." ${ }^{30}$ Widows and orphans receive entitlements mainly thanks to their relation to their husbands and fathers. The principles and the discourse related to survivor benefits put them within a familialist framework, under the assumption that men are the principal breadwinners of the family and that women are dependent on such a male-headed family for their livelihood. The state interferes at times of risk, such as the death of the male breadwinner, through survivor benefits to "protect" daughters and widows until they start to work, but mainly until they marry again. Hence, marriage itself has been regarded as an important social security mechanism for women. Accordingly, women have been encouraged to marry by means of marriage allowances, as a counter-measure to potential discouragement from marriage and extra-marital relations for fear of losing the pension. ${ }^{31}$ As for men, they have always been subjected to means-test since normally they were assumed to be the breadwinner. As a result of such assumptions about gender roles, however, survivor sons have been entitled to pensions in case of invalidity without any condition, whereas the pension of invalid daughters were terminated in case of marriage. This proves the assumption of women's dependency on the male-headed family and on marriage as the grounds for such gender-differentiated treatments, rather than a positive discrimination policy to compensate disadvantaged persons.

For these gender-specific policies providing more benefits to women, various reasons were stated in the parliamentary discussions of the Law of ES: the lack of employment opportunities for women; the prevention of women's dependency on persons outside the family and bureaucratic processes of means-test; and the reluctance to change the prevalent family structure which hinders women's participation in labor force in many

made sacrifices, and got injured," in TBMM, Zabıt Ceridesi, Term 8, Session 3, vol. 19, 18 May 1949. 507. Gürhan Çelebican addressed the parliament: "It is the most primary, sacred duty of our state to take under its protection the persons who try to maintain their lives without the patronage and the love of a husband and father, [that is,] the surviving widows and orphans of the members of our armed and police forces who died while fighting against terror for the indivisible integrity of our country [...] the support of our state will enable to win these children without fathers as youngsters beneficial to our country and nation," TBMM, Genel Kurul Tutanağı. Term 19, Legislation Year 5, 13 November 1995.

30 See Hüseyin Ekmekçioglu's address in the parliament, during which he stated: "Following the establishment of our Republic, the Great Leader Mustafa Kemal Atatürk emphasized in the most concise way that the Republican regime will protect our destitute citizens by saying that 'the Republic is especially the protector of the desolate." TBMM, Genel Kurul Tutanağı, Term 22, Legislation Year 1, vol. 24, 24 July 2003.

31 See R. Fehmen's address in parliament, TBMM, Zabit Ceridesi, Term 7, Session 2, vol. 18, 18 June 1945, 312-313 and Sait Azmi Feyzioğlu's (commission spokesperson) address, TBMM, Zabrt Ceridesi, Term 8, Session 3, vol. 19, 25 May 1949, 812. 
cases. ${ }^{32}$ On the one hand, these arguments refer to a positive discrimination approach to compensate for certain capability deprivations of women and to prevent a particular type of dependency; on the other hand, the approach to solve this problematic situation with a declared concern not to upset the prevalent gender order which in fact is a part of the problem means that the unfair gender relations rendering women the subordinate members of family and society are being reproduced. Hence, in this case genderdifferentiated treatment mostly means the satisfaction of certain immediate needs which are essentially defined in gendered terms.

Yet, the amendments which have equalized the benefits and conditions for survivor spouses of both sexes in the mid-1980s and the recent reform signal a move away from the assumed roles of breadwinner husband and dependent wife, towards a model of "universal breadwinner." This policy decreases stigmatization for both spouses, ending the means-test for men and the depiction of survivor wives as a particularly vulnerable group in need of protection.

\section{Healthcare insurance}

A similar gendered policy has been prevalent also in the healthcare benefits for dependents of insured persons. Again, the regulations for the healthcare insurance of civil personnel established gender norms which were adopted by the other two schemes in the mid-1980s and which have been maintained until now. Children of both sexes are subject to age-limit and marital status; however, daughters are entitled to healthcare regardless of age if they are not married and are likely to be considered "destitute" in the absence of help, while sons over the age limit are entitled only if they are disabled and "destitute." ${ }^{33}$ In the initial arrangements for the SSK and ES, the husband of an insured woman also was subject to means-test and agelimit, unlike the wife of an insured man; this was later changed to a genderneutral arrangement. ${ }^{34}$

Under the ongoing social security reform, in the General Health Insurance the dependents are defined as spouse, children, and parents, all of which are gender-neutral. Accordingly, the law offers a scheme of

32 See, especially, Tahsin Tüzün's address in parliament, TBMM, Zabit Ceridesi, Term 8, Session 3, vol. 19, 25 May 1949, 812ff.

33 Devlet Memurları Kanunu, Law No. 657, adopted on 14 July 1965, "Devlet Memurlarının Tedavi Yardımı ve Cenaze Giderleri Yönetmeliği," Resmi Gazete, no: 14622, 11 August 1973, and TC Emekli Sandığı Genel Müdürlügü. Emekli, Adi Malullük veya Vazife Malullügü Aylığı Bağlanmıs Olanlaria, Bunların Kanunen Bakmakla Yükümlü Bulundukları Aile Fertleri, Dul ve Yetim Aylı̈̆ Alanların Muayene ve Tedavileri Hakkında Tüzük (Ankara: Başbakanlık Basımevi, 1973).

34 Ozbek, Cumhuriyet Türkiyesi'nde Sosyal Güvenlik ve Sosyal Politikalar, 319, Güzel and Okur, Sosyal Güvenlik Hukuku (istanbul: Beta 2003): 503-04. 
healthcare which entitles all persons less than eighteen years of age to healthcare benefits, without any condition, while other persons are required to pay premium; if they are not able to pay, the state is supposed to pay the premium for them. Hence, the law excludes the former entitlement of daughters to lifelong health insurance. ${ }^{35}$

The termination of daughters' lifelong entitlement has been opposed as incompatible with the socio-cultural structure of Turkish society, ${ }^{36}$ adding the fact that most women at 25 are not economically independent, ${ }^{37}$ while the former entitlement was represented as devolving to girls from their "fathers"; hence, the law was depriving daughters of their acquired rights. ${ }^{38}$ Here, such an equal treatment policy might in the long run have a positive effect against familial dependency and stigmatization with paternalist protectionism for "the destitute." However, this equalization comes through cutting an actual provision enjoyed formerly by women, making them more vulnerable in the short run. Considering the position of women in the labor market-their employment rate was 22.3 percent in $2006^{39}$-a health system based on the employment variable means a high risk of insecurity for women. Such an equal treatment policy subjects women to the ideal of the male worker, not paying attention to the conditions under which women are currently living, as well as their gendered capabilities. A gender-sensitive approach should support another type of equal treatment policy in this case, for example, through a universal health system financed by taxes rather than premiums.

On the other hand, the arrangement of universal healthcare for all persons under the age of eighteen signals a change of the basis of children's entitlement, from familial dependency and the parents' labor market status to social citizenship. Such a universalist approach prevents the problem of

35 As stated above, this change concerns only the dependent daughters of the insured person; female survivors are still entitled to healthcare benefits regardless of age, under the same conditions as the survivor pensions mentioned above, without paying premiums in the new system. See the explanation of the Minister of Labor and Social Security Murat Başesgioglu on the issue, TBMM, Tutanak Dergisi, Term 22, Legislation Year 4, vol. 117, 19 April 2006, 26.

36 A member of the commision on the draft law, Ali Osman Salı, raised this idea with a minute of dissent, see TBMM, Plan ve Bütçe Komisyonu Raporu, Esas no: 1/1008, 1/8,1/14, 1/408, 1/568, $1 / 571,1 / 574,2 / 79,2 / 151,2 / 152,2 / 156,2 / 196,2 / 208,2 / 301,2 / 313,2 / 322,2 / 335,2 / 423,2 / 459$, 2/558, 2/593, 2/654, Decision no: 83, 06.04.2006. Available at: <http://www.tbmm.gov.tr/sirasayi/donem $22 /$ yil01/ss $1139 \mathrm{~m}$.htm>

37 See the remarks by Ibrahim Ozdoğan in parliament, TBMM, Tutanak Dergisi, Term 22, Legislation Year 4, vol. 117, 19 April 2006, 19.

38 See Kemal Kılıçdaroğlu's comment on the law, TBMM, Tutanak Dergisi, Term 22, Legislation Year 4, vol. 121, 30 May 2006, 53.

39 TURKSTAT, 2007. Available at <http://www.turkstat.gov.tr/PrelstatistikTablo.do?istab_id=575> 
formal-informal labor distinction for benefits, thus covering formerly uninsured children as well; moreover, it gives rights independent from family and, thus, promotes their personal autonomy.

\section{Retirement insurance}

While the initial legislations established retirement rules as genderneutral, ${ }^{40}$ the SSK formulated an early retirement for women in 1964, decreasing the minimum age from 60 to 55, while keeping the same age threshold for men, a policy which was later followed in the other two schemes as well. ${ }^{41}$ The SSK also re-adopted its earlier policy of the repayment of contributions to women workers who married and stopped working, which was exactly to enable working women to go back to the family when they married. ${ }^{42}$ Severance pay to which women workers have been entitled when leaving the labor market within one year following marriage has served the same purpose. ${ }^{43}$

This gendered policy has been preserved until today, even though in technical terms the provisions have been much amended. The standards finally converged between the three insurance schemes in 1999, by fixing the retirement age as 58 for women and 60 for men, while the minimum contribution days were 7,000 for workers and 9,000 for civil servants and the self-employed. ${ }^{44}$ As for the reform of 2006 , the current gendered policy is planned to continue until the year 2035; then, a gradual equalization in retirement ages will be applied until 2048, when the retirement age for both sexes will increase to 65 and the minimum contribution days to $9,000 .^{45}$

40 The thresholds were 55 years of age and 30 years of work for civil servants and 60 years of age and 25 years of work for workers, see ihtiyarlik Sigortası Kanunu of 1949, Maluliyet, ihtiparlik ve Olam Sigortalan Kanunu of 1957, and Emekli Sandiğ Kanunu of 1949.

41 For Bağ-Kur, 55 years of age for women and 60 years of age for men, along with a payment of contributions for at least 15 years. As for ES, the law was amended in 1975, decreasing the minimum requirement of working years to 20, while it was 25 for men. 5434 Sayul T.C. Emekli Sandığ Kanununun Bazı Maddelerinin Değistirilmesi ve Bir Geçici Madde Eklenmesi Hakkında Kanun, Law No. 1922, adopted on 3 July 1975.

42 See the Ihtiyarlik Sigortası Kanunu of 1949 and the justification for the law in "ihtiyarlik Sigortası Kanunu tasarısı ve Ekonomi, Cümrük ve Tekel ve Ulaştırma Komisyonlarının düşünceleri hakkındaki raporlarla Çalışma Komisyonu raporu (1/540)" TBMM, Zabıt Ceridesi, Term 8, Session 3, vol. 20, 1949,2 . The SSK law was amended to incorporate the policy by Law No. 899 , adopted on 13 July 1967.

43 See Art. 14/5 (amended on 25 August 1999) of /s Kanunu, Law No. 1475, adopted on 25 August 1971.

44 Law No. 4447, adopted on 25 August 1999.

45 Although these provisions were annulled by the Constitutional Court for civil servants, future formulations are likely to formulate the retirement conditions again on gender-neutral terms, considering the EU Acquis, especially "Council Directive 79/7/EEC of 19 December 1978 on the progressive implementation of the principle of equal treatment for men and women in matters of social security," which is included in Turkey's National Program. 
Initial arrangements established the entitlement of women to earlier retirement largely around the theme of family responsibilities of working women, assuming and reinforcing housekeeping and care as women's obligations. Women were again represented as secondary to men in the parliamentary discussions; gaining attention thanks to their role as "the main helper of her man." ${ }^{46}$ Moreover, women have been depicted as more vulnerable to physical deterioration, because of the double shift of domestic and paid labor under difficult conditions, along with the supposed biological weakness; hence, physical deterioration was shown as the major reason for the early retirement. ${ }^{47}$ Accordingly, the results of these tougher conditions were stated as a failure in domestic responsibilities, the lack of rest for women, and a decrease in the female labor force. ${ }^{48}$ Thus, parliament stated a group of broad objectives such as encouraging women to work and ensuring the family responsibilities of women-hence, the reproduction of the family and a new generation with national values. ${ }^{49}$

The solution, however, proposed only superficial relief for working women, instead of intervening in the underlying causes of the difficulties that women face-such as the gender division of labor at home and gendered organization of the labor market. The repayment of contributions when married female workers decide to leave the job market also underpins this policy of encouraging a return to home. While the need for employment-enabling services which would decrease the burden of care on women workers (such as day nurseries) were mentioned, ${ }^{50}$ there was no mention of the need to transform the gender division of labor in such a way as to provide an equal sharing of responsibilities, nor of the need to reorganize work life in a way to reconcile work and family life. Different treatment here again means the satisfaction of needs emerging from traditional gender roles and, in turn, the reaffirmation of these very roles.

46 See the address in parliament by Osman Ceran in TBMM, Tutanak Dergisi, Term 4, Session 2, vol. 13, 27 June 1975, 344.

47 See, for instance, the address in parliament by Ahmet Şener on his behalf in TBMM, Tutanak Dergisi, Term 4, Session 2, vol. 13, 27 June 1975, 339.

48 See the justification for the law draft "5434 Sayılı T.C. Emekli Sandığı Kanununun Değişik 39'uncu Maddesine Bir Fıkra Eklenmesi Hakkında Kanun Tasarısı ve Plan Komisyon Raporu (1/287)" TBMM, Tutanak Dergisi, Term 4, Session 2, vol. 13, 1975.

49 See, for instance, the address in parliament by Mehmet Hulusi Ozkul in TBMM, Tutanak Dergisi, Term 4, Session 2, vol. 13, 27 June 1975, 345 and the justification for the amendment law in "506 Sayılı Sosyal Sigortalar Kanunun Değişik 60'ıncı Maddesine Bir Fıkra Eklenmesine Dair Kanun Tasarısı ve Adana Milletvekili Alparslan Türkeş ve 2 Arkadaşının Teklifi ve Sağlık ve Sosyal İşler ve Plan Komisyonları Raporları (1/286, 2/133)," TBMM, Tutanak Dergisi, Term 4, Session 2, vol. 13, $1975,1$.

50 See the address in parliament by Fatma Gülhis Mankut in TBMM, Tutanak Dergisi, Term 4, Session 2, vol. 13, 27 june 1975, 340-41. 
On the other hand, parental leave might be helpful for the transformation of gender roles, as I will argue below. ${ }^{51}$

As for the aim of the retirement ages' gradual equalization with the recent reform, the ground for equal retirement is based on women's higher life expectancy. ${ }^{52}$ This fact is a more objective grounding and sounds more appropriate for the equal recognition of women than does a discourse of weakness and vulnerability. However, the existing double burden of domestic and paid labor for working women remains another problem for which early retirement used to be a superficial remedy, but the new policy entirely ignores this problem. Then again, such an equal treatment policy subjects women to the male ideal, ignoring family care responsibilities which usually cause interruption in women's employment. Furthermore, the equalization again appears to be a decrease of rights, increasing the ages for both women and men, rather than extending the same benefit to men, as was the case with pensions for the widowed. Thus, there is a general deterioration of rights regarding retirement.

\section{Maternity insurance and protective labor legislation}

The terms maternity insurance and protective labor legislation might remind of "naturally" gender-differentiated policies; yet, the meaning of differentiation and "protection" again depend on the context. When maternity insurance was established for workers in 1945, it was arranged for a total period of six weeks, in accordance with the Labor Law, but with a higher temporary incapacity allowance of 70 percent of the worker's daily wage (before, it had been half) and a breast-feeding allowance for the six weeks following the leave. ${ }^{53}$ Meanwhile, the aims of maternity insurance were connected to the population policies of the period-that is, to increase child birth, to ensure more efficient production, to improve living and working conditions, and to protect women. ${ }^{54}$

In 1950, healthcare benefits for pregnancy and delivery were added to the insurance, while the duration of paid leave was increased to a period of

51 In addition to parental leave and expansion of public services, examples from the Nordic countries can be given for the reorganization of work life-such as reducing the daily working hours of parents; interim part-time work with the option to return to full-time hours; bringing work home; and changing social security and tax incentives such as increasing after-tax earnings for part-time workers. See, UNDP, Human Development Report 1995: Gender and Human Development (New York: Oxford University Press, 1995), 8.

52 Ministry of Labor and Social Security, "Proposal for Reform in the Social Security System" (29 July 2004). Retrieved in 23.10 .2005 from <http://www.calisma.gov.trs.

53 Two-thirds of the maternity allowances for insured women were also provided in cash to the uninsured wife of the insured man. See is Kazalan, Meslek Hastaliklan ve Analk Sigortalan Hakkında Kanun.

54 See the address in parliament by Rebii Barkın, V. Sarıdal, and K. Kamü in TBMM, Zabıt Ceridesi, Term 7, Session 2, vol. 18, 15 June 1945, 270-285. 
nine weeks in total. ${ }^{55}$ Afterwards, the SSK law arranged the maternity insurance as it has been valid until now, with only a few amendments: healthcare benefits during pregnancy and delivery; breast-feeding allowance; and temporary incapacity allowance, along with a maternity leave of a period of twelve weeks in total. As for civil servants, Law No. 657 arranged maternity benefits in 1965 , with a total of nine weeks of paid maternity leave; a non-paid leave of up to twelve months on request; a three-day leave for civil servant husbands in case of his wife's child delivery; a daily breast-feeding break (one hour and a half) for six months following the maternity leave; and family allowances paid to the husband if both spouses are civil servants. Finally, maternity leave was increased to a total of sixteen weeks for both civil servants and workers, following the Labor Law of $2003 .{ }^{56}$ Here, the aim of the amendment was stated as the encouragement and facilitation of women to work, ensuring both health and working rights during maternity, as well as the requirement of the relevant EU directive. ${ }^{57}$ In addition, the reform of 2006 extends the breastfeeding allowance to all insured persons (the ES and the Bag-Kur have not included such a benefit) for a period of six months, with the amount of onethird of the minimum wage, together with the plan on incorporating maternity insurance into Bağ-Kur in accordance with the National Program. ${ }^{58}$

Another commitment of the National Program concerns parental leave and requires the harmonization of the labor legislation, parallel to Directive 96/34/EC on parental leave. ${ }^{59}$ In the previous parliament, there was on the agenda a draft law which defined parental leave right for civil servants and workers. ${ }^{60}$ The draft became void due to the parliamentary

55 Hastalik ve Analik Sigortası Kanunu, Law No. 5502, adopted on 4 January 1950.

56 For the amendment of the SSK, see Law No. 4958, adopted on 29 July 2003, for the ES see Law No. 5223, adopted on 14 July 2004.

57 See the commision report in "Ankara Milletvekili Oya Araslı ve 10 Milletvekilinin; 657 Sayılı Devlet Memurları Kanununun Bazı Maddelerinin Değiştirilmesi Hakkında Kanun Teklifi ile İstanbul Milletvekili Zeynep Karahan Uslu ve 9 Milletvekilinin; Devlet Memurları Kanununda Değişiklik Yapılması Hakkında Kanun Teklifi ve Plan ve Bütçe Komisyonu Raporu (2/211, 2/221)," TBMM, Tutanak Dergisi, Term 22, Legislation Year 2, vol. 57, Order no. 637, 2004. The relevant directive is "Council Directive 92/85/EEC of 19 October 1992 on the implementation of measures to encourage improvements in the safety and health of pregnant workers, women workers who have recently given birth and women who are breastfeeding."

58 This arrangement is planned in the National Program specifically for the transposition of the "Council Directive 86/613/EEC of 11 December 1986 on the application of the principle of equal treatment between men and women engaged in an activity, including agriculture, in a self-employed capacity, and on the protection of self-employed women during pregnancy and motherhood."

59 "Council Directive 96/34/EC of 3 June 1996 on the framework agreement on parental leave concluded by UNICE, CEEP and the ETUC."

60 “Devlet Memurları Kanunu ve iş̧ Kanununda Deģişiklik Yapılmasına Dair Kanun Tasarısı ve Avrupa 
elections, yet it is very likely to come to the agenda again. According to this draft, an unpaid parental leave of up to twelve months following paid maternity leave has been defined for the female civil servant or her husband who is also a civil servant on their request. For workers, the leave has been set as up to six months for the female worker and her husband who also is a worker and could be extended to twelve months on request. The leaves can be used successively on the spouses' request, and the labor contracts of persons on paternal leave cannot be annulled because of the leaves. These rights also apply in case of the adoption of a child at maximum three years of age.

As it has been demanded by feminists, women, and labor organizations, ${ }^{61}$ the shift from maternal leave to parental leave is important for the transformation of the gender division of labor and reconciliation of work and family life, making the equal sharing of responsibilities within the family possible. Here, such an equal treatment policy sets out from the principle of care per se, instead of care as an obligation of women. In addition, giving the right to leave to both parents can operate against the problem of a preference for male workers, since it almost equalizes the burden of female and male workers for the employers. However, as examples from European countries show, men are unlikely to take leave when it is not paid, and the leave might promote both women's labor market participation and exit in different contexts. ${ }^{62}$ Therefore, such a transformation needs not just the reorganization of family life, but also the expansion of public services and a reorganization of the labor market. Accordingly, other demands include the obligation of employers to provide day nurseries according to the number of all workers instead of just female ones; the increase in number and improvement of day nurseries; calculation of unpaid maternal leaves within the retirement requirement; and so on. ${ }^{63}$ The AKP government, on the other hand, does not seem to further any developments regarding the care issue, given its recent remarks about ending the responsibility of both public and private employers to provide day nurseries alongside an uncertain project of a Maternity Fund

Birliği Uyum; Sağlık, Aile, Çalışma ve Sosyal İ̧ler ile Plan ve Bütçe Komisyonları Raporları (1/948)," TBMM, Tutanak Dergisi, Term 22, Legislation Year 3, 2005, Order No. 834. Available at: <http://www.tbmm.gov.tr/sirasayi/donem22/yil01/ss834m.htm/>.

61 "Her İ̧yerine Kreş, Erkeklere Doğum Izni," Bianet, 09/04/2003, Türk-iş, "Türkiye'de Emek Piyasasında Kadınların Durumu," 2005, Arın and Ergin, Türkive'de Sosyal Güvence ve Kadınlar, Koray, Sosyal Politika.

62 Gwennaele Bruning and Janneke Plantenga, "Parental Leave and Equal Opportunities: Experiences in Eight European Countries," Journal of European Social Policy, 9, 3 (1999).

63 "Kadınlar Orgütlenip Haklarını Almalı," Bianet, 27/08/2007, Yelda Yücel, "2000'li Yıllarda Ekonomi ve Kadınlar Cephesinde Cörünüm," Pazartesi, 112 (February-March 2007). 
for women workers. ${ }^{64}$ Nevertheless, the adoption of parental leave, together with the later retirement age, can still be seen as a move away from the policy of supporting women's return to home and towards a policy of encouraging female employment.

Here, the amendment regarding women's night work is another example for such a change of policy. Parallel to Directive 2002/73/EC on equal treatment, the Labor Law of 2003 abandoned the long-lasting prohibition on women's night work in industry; hence, only persons less than eighteen years of age are prohibited from night work in industry. ${ }^{65}$ Such protective measures present a more complex issue from a gender perspective. On the one hand, like several other gender-differentiated policies, the prohibitions and restrictions on the employment of women in specific types of work appear to be shaped mostly by gender stereotypes and norms. Accordingly, barring women from night work and certain kinds of work classified as hard or dangerous depicts women as the "weaker sex" in need of paternalist protection, while sometimes helping employers to deal with the issue without taking measures against risks endangering all workers, thus leaving men unprotected. ${ }^{66}$ The abandonment of the prohibition also might seem progressive because it provides equal opportunities for women and men in terms of access to employment. On the other hand, the abandonment might have more to do with the deregulation of the labor market and giving flexibility to employers, rather than aiming to improve the working chances of women who would likely prefer night work in order to handle the problem of double shift, if not obliged by the employer at all. ${ }^{67}$ Then again, this might be seen as a step backwards in the regulation of the labor market in the form of granting women formal equality with men.

\section{Concluding remarks}

The social policies examined above cover an array of issues over a long period of time; yet, in the mentality behind these approaches one can observe great continuity since the late Ottoman period up to the last two

64 "Kreş de Olsa, Fon da Kurulsa, Hükümetin Kadına Bakışı Aynı," Bianet, 15/01/2008.

65 "Directive 2002/73/EC of the European Parliament and of the Council of 23 September 2002 amending Council Directive $76 / 207 / \mathrm{EEC}$ on the implementation of the principle of equal treatment for men and women as regards access to employment, vocational training and promotion, and working conditions."

66 Valentine Forastieri, "Information Note on Women Workers and Cender Issues on Occupational Safety and Health," (Ceneva: International Labor Office, 2000). Available at: <http://www.ilo.org/public/english/protection/safework/gender/womenwk.htm\#N_10_>

67 See Jane Lewis and Celia Davies, "Protective Legislation in Britain, 1870-1990: Equality, Difference and Their Implications for Women," Policy and Politics, 19, 1 (1991). 
decades. The underlying assumptions and principles represent women as a weaker, more vulnerable group in need of special protection, stigmatizing them as "the destitute." The provisions reinforce familial dependency and the gender division of labor both in the domestic sphere and paid employment. Policies were established around a normative family model in which men are the principal breadwinners and women are kept by the male heads of families, either fathers or husbands. Thus, women receive entitlements such as healthcare on the basis of the labor market status of these men, while the state interferes in the absence of these breadwinners to "protect destitute women" until they start to work or, more likely, marry. Here, the gendered treatment of disabled orphans clearly shows the assumption that women are, or should be, kept by their husbands and that different treatment for women relates mainly to the absence of this male breadwinner, rather than positive discrimination. However, policy changes since the mid-1980s have gradually equalized some of the conditions for survivor benefits (through extension) and, more recently, healthcare (through decrease), and these changes signal a move away from the ideal of the "male breadwinner family" and towards a model of the "universal breadwinner."

The familialist approach also prevailed in policies regarding working women. Housekeeping and care were assumed and reinforced as the obligations of women. In addition to the repayment of contributions and severance pay, the possibility of early retirement encouraged women to go back home and perform their familial duties. Hence, the remedies were likely to reinforce the existing gender norms and relations, which underlie the difficulties women face, instead of transforming them. However, recent initiatives aiming to turn maternal leave into parental leave are promising for such a transformation, signaling a move away from the ideal of a "female carer" and towards that of a "universal carer." Considering also that the prohibition on women's night work has been lifted and that retirement rules were equalized (through decrease), recent changes signal a transition from the policy of supporting the return of women to home towards a policy of encouraging female employment.

Overall, former policies show a relative continuity, leaning towards an approach of different treatment and reinforcing gendered identities based on traditional norms. On the other hand, recent changes have shifted towards an approach of equal treatment, mostly through the decrease of benefits formerly enjoyed only by women, instead of their extension to men; again, this does not constitute an intervention in the underlying causes of the problems that women face. The gender dimension of the recent reform bills seems to be mostly shaped by the EU harmonization 
process, although there have been relevant demands by feminists, women workers, and unionists for a long time. Yet, the influence of the EU on gender equality has not been entirely positive. The government has adopted the principle of equal treatment suggested by EU directives on gender and social policy mostly through a decrease of social rights. The AKP government's move away from such a long-lasting policy of "protecting" women and toward formal gender equality might seem ironic at first, given its conservative stance, but it is quite consistent with its neoliberal side, the dominant component of the formula. ${ }^{68}$

The policies and discourses examined above point to a need for a gender-sensitive approach which has to take into account gender differences and inequalities, as well as other intersecting axes of differentiation and domination in society, while showing caution about the risks of essentialism and stigmatization due to differentiated treatments. Hence, a reconsideration of the place of women in social policy is necessary for developing such policies in order to assure women's well-being and equal participation in society. As for the other side of the coin-that is, how women and men (whether workers, unionists, employers, or feminists) have influenced the formation of these policies throughout history and how these policy issues have been experienced and redefined in everyday life practices-these are subjects for further research. Such research is important particularly to remind that women and men are not merely clients or apolitical clients in the face of welfare state policies.

\section{A list of major legislative arrangements (in chronological order)}

"Infak-1 Muhtacin-i Eytam ve Eramil-i ilmiyye Nizamnamesi," Date of Adoption: 27.09.1874. In Kamu Personeli Emeklilik Mevzuatı 1 (1876-1930) Ankara: Maliye Bakanlı̆̆ı Bütçe ve Mali Kontrol Genel Müdürlüğ̈ü, 1994.

"Memurin-i Mülkiye Terakki ve Tekaüd Kararnamesi," Date of Adoption: 26.09.1880. In Kamu Personeli Emeklilik Mevzuatı 1(1876-1930) Ankara: Maliye Bakanlığı Bütçe ve Mali Kontrol Cenel Müdürlüğü, 1994.

"No: 77 - 2 zilkade 1305 tarihli devairi askeriyede müstahdem memurin ve ketebei tekaüd nizamnamesinin 19 ve 21 inci maddesi musahhası," Date of Adoption: 13.04.1889. In Kamu Personeli Emeklilik Mevzuatı 1 (1876-1930) Ankara: Maliye Bakanlığı Bütçe ve Mali Kontrol Genel Müdürlüğüu, 1994.

"No: 119 - Erkan, ümera ve zabitanı askeriyeden vefat edenlerin eytam ve eramiline tahsis olunacak maaşlara mütedair 12 şaban 1306 tarihli 5 inci maddei musahhasına müzeyyel fikrai nizamiye." Date of Adoption: 10.10.1889 In Kamu Personeli Emeklilik Mevzuatı 1 (1876-1930) Ankara: Maliye Bakanlığı

68 The AKP also proposes familialist policies when they are consistent with the neoliberal agenda, as in the example of social work, see Berna Yazıcı, "Social Work and the Politics of the Family at the Crossroads of Welfare Reform in Turkey" (Ph.D. Diss., New York University, 2007) 
Bütçe ve Mali Kontrol Genel Müdürlüğ̈ü, 1994.

Muhtacın Maaşatı Hakkında Nizamname. Date of Adoption: 27.6.1910. In Republic of Turkey, Düstur, 2nd Tertib, vol. 2, 400-03.

Umumi Hifzisihha Kanunu, Law no: 1593, Aproval Date: 24.04.1930.

Askeri ve Mülki Tekaüd Kanunu, Law no: 1683, Date of Adoption: 03.06.1930.

is Kanunu, Law no: 220, Date of Adoption: 08.06.1936.

ILO 45 numbered Convention concerning the Employment of Women on Underground Work in Mines of all Kinds, Date of Adoption by ILO: 21.06.1935. Date of Adoption by Turkey: 09.06.1937, no: 3229.

iş Kazaları, Meslek Hastalıkları ve Analık Sigortaları Hakkında Kanun, Law no: 4772, Date of Adoption: 27.06.1945.

ihtiyarlık Sigortası Kanunu, Law no: 5417, Date of Adoption: 02.06.1949.

Emekli Sandığı Kanunu, Law no: 5434, Date of Adoption: 08.06.1949.

Hastalık ve Analik Sigortası, Law no: 5502, Date of Adoption: 04.01.1950

5502 savılı Hastalık ve Analık Sigortası Kanunun bazı maddelerinin değiștirilmesine, bir maddesinin kaldırimasına ve muvakkat madde eklenmesine dair Kanun, Law no: 6901, Date of Adoption: 04.02.1957.

Maluliyet, Ihtiparlik ve Olüm Sigortaları Kanunu, Law no: 6900, Date of Adoption: 04.02.1957.

Sosyal Sigortalar Kurumu Kanunu, Law no: 506, Date of Adoption: 17.07.1964.

Devlet Memurları Kanunu, Law no: 657, Date of Adoption: 14.07.1965.

is Kanunu, Law no: 931, Date of Adoption: 28.07.1967.

Is Kanunu, Law no: 1475, Date of Adoption: 25.08.1971.

Esnaf ve Sanatkarlar ve Diğer Bağımsız Çalışanlar Sosyal Sigortalar Kurumu Kanunu, Law no: 1479, Date of Adoption: 02.09.1971.

506 sayılı sosyal sigortalar kanunun bazı maddelerinin değiştirilmesi ve bu kanuna iki geçici madde eklenmesi hakkında kanun, Law no: 1753, Date of Adoption: 21.06.1973.

"Devlet Memurlarının Tedavi Yardımı ve Cenaze Giderleri Yönetmeliği," Resmi Gazete, no: 14622. 11.08 .1973$.

T.C. Emekli Sandığı Genel Müdürlüğü. Emekli, Adi Malullük veүa Vazife Malullüğü Aylığı Bağlanmış Olanlarla, Bunların Kanunen Bakmakla Yükümlü Bulundukları Aile Fertleri, Dul Ve Yetim Aylı̆̆ı Alanların Muayene Ve Tedavileri Hakkında Tüzük. Ankara: Başbakanlık Basımevi, 1973.

5434 Sayılı T.C. Emekli Sandığı Kanununun Bazı Maddelerinin Değiştirilmesi ve Bir Geçici Madde Eklenmesi Hakkında Kanun, Law no: 1922, Date of Adoption: 03.07.1975.

Iş Kanunu, Law no: 4857, Date of Adoption: 22.05.2003.

Esnaf ve Sanatkarlar ve Diğer Bağimsiz Calışanlar Sosyal Sigortalar Kurumu Kanumunun ve Tarimda Kendi Adına ve Hesabına Çalişanlar Sosyal Sigortalar Kanununun Bazı Maddelerinin Değiştirilmesi, Yürürlükten Kaldıriması ve Bu Kanunlara Ceçici Maddeler EkJenmesi Hakkında Kanun, Law no: 4956, Date of Adoption: 24.07.2003.

Sosyal Sigortalar Kurumu Kanunu, Law no: 4958, Date of Adoption: 29.07.2003.

"Avrupa Birliği Müktesebatının Üstlenilmesine İlişkin Türkiye Ulusal Programı," Resmi Gazete, no: 25178, 24.07.2003.

Sosyal Sigortalar ve Genel Sağlık Sigortası Kanunu, Law no: 5489, Date of Adoption: 19.04.2006. 


\section{References}

Acar-Savran, Cülnur. "AB'nin Toplumsal Cinsiyet Politikaları," Birikim, 204 (April 2006): 40-54.

—. Beden, Emek, Tarih: Diyalektik Bir Feminizm Için. Istanbul: Kanat, 2004.

—. "Sosyal Cüvenlik Reformu Karşısında Feminist Politika," Bianet (4 January 2008).

—. Interview. "Ev iş̧leri Bütün Bir Hayata Yayılır," Pazartesi, 112 (February-March 2007): 41-50.

Acuner, Selma. "Avrupa Birliği ve Eşitlik Politikaları: Çetrefil Bir Yol!" Amargi, 2 (Fall 2006): 75.79.

Anonymous. "Pozitif Ayrımcılık Bize Fena Halde Gereklidir..." Petrol-is Kadın, 9 (June 2004): 4-6.

Arat, Yeşim. "Türkiye'de Toplumsal Cinsiyet ve Vatandaşlık." In 75 Yilda Tebaa'dan Yurttaş'a Doğru, edited by Artun Ünsal, 67.74. İstanbul: Tarih Vakfi, 1998.

Arın, Tülay and Berin Ergin. "Türkiye'de Sosyal Güvence ve Kadınlar: Yasal Çerçeve ve Uygulama." In Aydinlanmanin Kadinları, edited by Necla Arat, 212-70. İstanbul: Cumhuriyet Kitapları, 1998.

Bianet. "Her İ̧̧yerine Kreş, Erkeklere Doğum İzni" (09 April 2003).

—. "Kadın İstihdamı için Talepler: Pozitif Ayrımcılık" (11 December 2007).

—. "Kadınlar Örgütlenip Haklarını Almalı" (27 August 2007).

—. "Kadınlar Sosyal Cüvenlik Reformuna Karşı Eylem Hazırlığında" (31 December 2007).

—_. "Kreş de Olsa Fon da Kurulsa Hükümetin Kadına Bakışı Aynı," (15 january 2008).

Bock, Cisela and Susan James. "Introduction: Contextualizing equality and difference." In Beyond Equality and Difference: Citizenship. Feminist Politics, and Female Subjectivity, edited by Gisela Bock and Susan James, 3-13. London, NY: Routledge, 1992.

Bora, Aksu. Kadınların Sınıfi: Ücretli Ev Emeği ve Kadın Öznelliğinin Inş̧ası. İstanbul: İletişim, 2005.

Bruning, Gwennaele and Janneke Plantenga, "Parental Leave and Equal Opportunities: Experiences in Eight European Countries," Journal of European Social Policy, 9, 3 (1999): 195-209.

Buğra, Ayşe. "Poverty and Citizenship: An Overview of the Social Policy Environment in Republican Turkey," International Journal of Middle East Studies, 36 (2007): 27.46.

Buğra, Ayşe and Çağlar Keyder. "Turkish Welfare Regime in Transformation," Journal of European Social Policy, 16, 3 (2006): 211-28.

Çalışma ve Sosyal Güvenlik Bakanlı̈̆ı. "Proposal for Reform in the Social Security System," 29 July 2004. Retrieved in 23 October 2005 online from: <http://www.calisma.gov.tr>.

Çanlı, Mehmet. "Eytam Idaresi ve Sandıkları (1851-1926)." In Türkler, 57.73. Ankara: Yeni Türkiye Yayınları, 2002.

_. "Eytam Idaresi-Sandıkları ve Osmanlı Devletinde Yetimlerin Ekonomik Haklarının Korunması." In Savaş Çocuklarl: Öksüzler ve Yetimler, edited by Emine Gürsoy-Naskali and Aylin Koç, 59-86. Istanbul: [s.n.], 2003.

Ecevit, Yıldız. "Women's Labour and Social Security." In Bridging the Gender Cap in Turkey: A Milestone towards Faster Socio-economic Development and Poverty Reduction, edited by. Feride Acar. Poverty Reduction and Economic Management Unit: World Bank, 2003.

EU. "Council Directive $79 / 7 /$ EEC of 19 December 1978 on the progressive implementation of the principle of equal treatment for men and women in matters of social security"

- "Council Directive 86/613/EEC of 11 December 1986 on the application of the principle of equal treatment between men and women engaged in an activity, including agriculture, in a self-employed capacity, and on the protection of self-employed women during pregnancy and motherhood."

-. "Council Directive 92/85/EEC of 19 October 1992 on the implementation of measures to encourage improvements in the safety and health of pregnant workers, women workers who have recently given birth and women who are breastfeeding." 
concluded by UNICE, CEEP and the ETUC."

"Directive 2002/73/EC of the European Parliament and of the Council of 23 September 2002 amending Council Directive 76/207/EEC on the implementation of the principle of equal treatment for men and women as regards access to employment, vocational training and promotion, and working conditions."

Forastieri, Valentine, "Information Note on Women Workers and Gender Issues on Occupational Safety and Health." Ceneva: International Labor Office, 2000. Available at: <http://www.ilo.org/public/english/protection/safework/gender/womenwk.htm\#N_10_>.

Güzel, Ali, and Ali Rıza Okur. Sosyal Güvenlik Hukuku. 9 ed. Istanbul: Beta, 2003.

ilkkaracan, İpek. "Göç, Kadının Ekonomik Konumu, Hareket Ozgürlügü ve Aile Içi Güç Dinamikleri," iktisat Dergisi, 337 (March 1998): 62-67.

Kala, Eyüp Sabri. "Osmanlılarda Sosyal Güvenlik - Sosyal Sigortalar, (1865-1923)." MA Thesis, İstanbul University, 1994.

KESK. "Olumlu Eylem ve Cüçlendirme Raporu," 2004. Available at <http://www.kesk.org.tr/index.php?option=com_content\&task=view\&id=56\&|temid=119>

Koray, Meryem. Sosyal Politika. Ankara: Imge, 2005.

Kümbetoglu, Belkıs. Women's Informal Sector Contribution to the Household Survival in Urban Turkey. Ph.D. Dissertation, İstanbul University, 1992.

Lacey, Nicola. "The Constitution of Identity: Gender, Feminist Legal Theory, and the Law and Society Movement." In The Blackwell Companion to Law and Society, edited by Austin Sarat, 471-86. Malden: Blackwell, 2004.

Lewis, Jane and Celia Davies. "Protective Legislation in Britain, 1870-1990: Equality, Difference and Their Implications for Women," Policy and Politics, 19, 1 (1991): 13-25.

Makal, Ahmet. Türkiye'de Tek Partili Dönemde Çalışma ilişkileri: 1920-1946. Ankara: Imge, 1999.

Maliye Bakanlı̈̆ı Bütçe ve Mali Kontrol Cenel Müdürlügü. Kamu Personeli Emeklilik Mevzuatı I (18761930). Ankara: Maliye Bakanlığı Bütçe ve Mali Kontrol Genel Müdürlüğü, 1994.

- Kamu Personeli Emeklilik Mevzuatı II (1930-1950). Ankara, Maliye Bakanlığı Bütçe ve Mali Kontrol Genel Müdürlüğü, 1995.

Oktay, Aygül. "i̧̧ Yerinde Cinsel Taciz ve İstismar," Kadın Araştırmalor Dergisi, 7 (2001): 75-89.

Os, Nicole A. N. M. Van. "Asker Ailelerine Yardım: Osmanlı Devleti ve Muinsiz Aile Maaşı." In Devletin Silahlanmass: Ortadoğu ve Orta Asya'da Zorunlu Askerlik, 1775-1925, edited by Erik J. Zürcher, 105-21. İstanbul: İstanbul Bilgi Üniversitesi Yayınları, 2003.

Ozbay, Ferhunde (ed). Küresel Pazar Açısından Kadın Emeği ve istihdamındaki Değişmeler: Türkiye Örneği. Istanbul: İnsan Kaynağını Geliştirme Vakfi, 1998.

Ozzbek, Nadir. Cumhuriyet Türkivesi'nde Sosyal Güvenlik ve Sosyal Politikalar. Istanbul: Tarih Vakfi, 2006.

—. Osmanl Imparatorluğu'nda Sosyal Devlet: Siyaset, iktidar ve Meşruijet, 1876-1914. İstanbul: Illetişim, 2004.

Ozcan, Tahsin. "Osmanlı Toplumunda Sosyal Güvenlik Üzerine Bazı Gözlemler." In Osmanlı, 110-15. Ankara: Yeni Türkiye yayınları, 1999.

Scott, Joan W. "Deconstructing Equality-versus-Difference: Or, the Uses of Post-structuralist Theory for Feminism," Feminist Studies, 14, 1 (Spring 1988): 33-50.

TВMM. Zabit Ceridesi, Term 3, Session 3, vol. 20, 1930.

—. Zabıt Ceridesi, Term 7, Session 2, vol. 18, 1945.

—. Zabit Ceridesi, Term 8, Session 3, vol. 19, 1949.

—. Zabit Ceridesi, Term 8, Session 3, vol. 20, 1949.

—. Tutanak Dergisi, Term 4, Session 2, vol. 13, 1975. 
—. Tutanak Dergisi, Term 17, Legislation Year 2, vol. 14, 1985.

- Cenel Kurul Tutanağı, Term 19, Legislation Year 5, 13 November 1995. Available at: <http://www.tbmm.gov.tr/develop/owa/tutanak_ss.birlesim_baslangic?P4=549\&P5=T\&web_user_i $d=3507868 \&$ PACE $1=1 \&$ PAGE2 $=54>$.

—. Tutanak Dergisi, Term 22, Legislation Year 1, vol. 24, 2003.

- Tutanak Dergisi, Term 22, Legislation Year 2, vol. 57, 2004.

—. "Devlet Memurları Kanunu ve İş Kanununda Değişiklik Yapılmasına Dair Kanun Tasarısı ve Avrupa Birliği Uyum; Sağlık, Aile, Çalışma ve Sosyal İşler ile Plan ve Bütçe Komisyonları Raporları (1/948)," in Tutanak Dergisi, Term 22, Legislation Year 3, Order no. 834, 2005. Available at: <http://www.tbmm.gov.tr/sirasayi/donem22/yil01/ss834m.htm>.

$z$ - Tutanak Dergisi, Term 22, Legislation Year 4, vol. 117, 2006.

—. Tutanak Dergisi, Term 22, Legislation Year 4, vol. 121, 2006.

—. "Plan ve Bütçe Komisyonu Raporu," Esas no: 1/1008, 1/8,1/14, 1/408, 1/568, 1/571, 1/574, 2/79, 2/151, 2/152, 2/156, 2/196, 2/208, 2/301, 2/313, 2/322, 2/335, 2/423, 2/459, 2/558, 2/593, 2/654, Decision no.: 83, 6 April 2006. Available at: <http://www.tbmm.gov.tr/sirasayi/donem22/yil01/ss I139m.htm>.

Toksöz, Gülay and Seyhan Erdoğdu. Sendikacı Kadın Kimliği. Ankara: İmge, 1998.

Toprak, Zafer. "Sosyal Politika Tarihimizin Ilk Onlemler Paketi: Müessesat-ı Sınaiyyede Çocukların ve Kadınların Calıştırılması (1910)." Toplum ve Bilim 27 (Fall 1984): 229-37.

Türk-Iş. "Türkiye'de Emek Piyasasında Kadınların Durumu," 2005. Available at <http://www.turkis.org.tr/icerik/avparkadin.doc>

UNDP. Human Development Report 1995: Gender and Human Development. New York: Oxford University Press, 1995.

Yazicl, Berna. Social Work and the Politics of the Family at the Crossroads of Welfare Reform in Turkey. Ph.D. Dissertation, New York University, 2007.

Yücel, Yelda. "2000'li Yıllarda Ekonomi ve Kadınlar Cephesinde Görünüm," Pazartesi, 112 (February. March 2007): 70.73.

Zırhlı, Fatma Şenden. Sosyal Güvenlik ve Kadın. İstanbul: Minerva, 2000. 